\title{
SLFN11 wt Allele
}

National Cancer Institute

\section{Source}

National Cancer Institute. SLFN11 wt Allele. NCI Thesaurus. Code C116957.

Human SLFN 11 wild-type allele is located in the vicinity of $17 q 12$ and is approximately 23 $\mathrm{kb}$ in length. This allele, which encodes Schlafen family member 11 protein, is involved in the response to viral infection. 